\title{
Developing Political Conversations?
}

Professor Nick Ellison and Dr Johanne Orchard-Webb*

University of Leeds (UK)

School of Sociology and Social Policy, Leeds, LS2 9JT

*Corresponding author: J.M.Orchard-Webb@Leeds.ac.uk

\begin{abstract}
This paper seeks to develop an understanding of the role played by social media (in the English context) in shaping the nature of localized political engagement between citizens and local authorities. Drawing on a survey of all English local authorities and initial work in developing three in-depth case studies, the paper examines the utilization of social media before going on to ask what potential these media might hold for the enhancement of local participation. Amidst contemporary debates about the nature of local governance, not least those prompted by recent UK government preoccupation with the 'Big Society' (Cameron, 2010) and its introduction of a new Localism Bill (2011), Web 2.0 platforms such as Facebook and Twitter afford new opportunities for online interaction - characterized here as 'political conversations' - that could contribute to the reinvigoration of the local public sphere. In particular these platforms could encourage forms of participation that would bridge the divide that has emerged in recent years between residents as consumers of local services and residents as citizens, or local democratic actors. Further the paper outlines questions emerging from case study scoping for a new research project exploring the impact of the use of social media in local government upon citizen engagement and political praxis. The questions are concerned with the impact these media have upon stubborn citizen engagement issues around accessibility, depth of representation, tokenism, poor citizen feedback, consultation fatigue, democratic deficit and inequalities of power within state-shaped platforms of engagement.
\end{abstract}

The Manichean nature of this debate often casts social media and the internet as offering either a dystopian or utopian potential with regard to citizen engagement and democratic political potential (Anduiza et al. 2009; Ellison and Hardey, 2012; Pajnik, 2005). Offering a synthesis of these debates the first section of this paper outlines the dominant areas of investigation researched by the academy in relation to social media and political engagement. It then makes the argument based on the survey of UK local government by Ellison and Hardey (2012) that there is an under-researched and indeed under-utilised potential space between these polemic positions of low-level, but nevertheless important 'political conversations' between local government and citizens. It is our belief that such open-ended conversations on local political issues, via social media, require greater attention in order to begin to address the neglect by the academy of these less formally constituted episodes of public participation in relation to political citizenship (Ellison and Hardey, 2012). The paper will then go on 
to briefly outline the current research project being undertaken by the authors to explore this space further in three detailed English case studies. The paper concludes with initial themes emerging from scoping for this project and a discussion of how these relate to research questions around the relationship between a rapidly maturing social media ecology and the nature of citizen/(local) state relations within a public sector austerity and localism context.

\section{Political citizenship in a mediated society - a synthesis of recent key debates}

Research exploring the democratic potential of social media and citizen-state relations has been dominated by three streams of investigation in recent years. The first is concerned with the practicalities and efficiencies of social media as an additional information-providing platform or service delivery medium with evident links to how this contributes to a form of citizenship dominated by practices of consumption (i.e. the citizen consumer) (Newman and Clarke, 2009). This focus reflects the fact that $73 \%$ UK Internet users access some form of government service online (Dutton and Blank, 2011). The second focus has been to report on and critique experiences of large-scale government e-democracy models such as national and regional scale consultations, e-petitions and online voting mechanisms (Lindner and Riehm, 2010; Miller, 2009). This model has evolved with the advent of Web 2.0 technologies with consideration of a more 'open source' (many-to-many) configuration of political engagement that offers potential for more deliberative political exchange (Dahlberg, 2001; O'Reilly, 2010; Rheingold, 2000) but perhaps relies on a form of libertarian 'active citizenship'. This model is critiqued for its exclusionary practices and the risk of post-political citizenship (Loader and Mercea, 2011; Pajnik, 2005). The third stream has emerged in work exploring the effectiveness of social media as a political campaign tool (Tapscott, 2009). The latter was especially triggered by use of social media by the Obama presidential election campaign in the USA in 2008 to achieve highly effective online and offline canvassing (Tapscott, 2009). While these are all important elements of the relationship between the state and citizens, as mediated by social media and Web 2.0 technologies, there is much less said about the day-to-day potential for political conversations at a local government level (Ellison and Hardey, 2012). It will be argued that exploring the link between this evolving mode of participation and local government/citizen conversations is key to a more nuanced critical engagement with political citizenship and praxis in the UK today.

The more utopian aspect of the debate can be seen in the early research on the internet (Norris, 1999) and in more reflective but still optimistic work more recently by Dahlgreen (2009) and Zavestoski, (2006) who have argued the case for the democratising potential of the Internet. Others have since argued that the naïve optimism of early academic champions and web entrepreneurs was founded on a misplaced faith in the alleged common values of 'transparency', 'universal access' and 'freedom of voice' shared by internet-based communications and aspirations for a progressive Habermasian style deliberative democracy (Dean, 2003; Pajnik, 2005). As we will see below the presence of these values 
in Internet communications is uneven in coverage, and how this shapes citizen political praxis and the reality of the 'political conversations' potential of social media engagement must continue to be critically reviewed. Nevertheless, this early optimism has been reinvigorated by the arrival of Web 2.0 technology and in particular social media platforms such as Facebook and Twitter (O'Reilly, 2010). The use of social media to act as a catalyst for acts of real world democratic protest during the Arab Spring in Tunisia, Egypt and Libya 2011/12 have been widely commented upon in this vain (Dutton, 2013; Foresight Future Identities, 2013).

With the increasing adoption, of Web 2.0 technologies from 2009 onwards O'Reilly (2010) presented his libertarian thesis for 'Government 2.0.' This form of government he suggested would enable and empower self-sufficient/ self-organizing citizens via Web 2.0 platforms and citizen access to open data. This citizen/state relationship was presented in contrast to traditional forms of bureaucratic government that he maintains propagates state dependency. Government 2.0 uses technology to extend and accelerate the shift from government to governance beyond the state (Jessop, 2002) that seeks to answer societal challenges through active citizen participation (Lowndes and Pratchett, 2012). The neo-liberal ideology underlining Government 2.0 argues this networked relationship between the state and other stakeholders is enabling citizen consumers the freedom to choose based on their individual needs. This new relationship is characterised as being more responsive, self-sufficient and importantly - in light of the pervasive austerity public sector policies across many Western democracies - more cost-effective (O’Reilly, 2010).

Such "grand narratives celebrating the Internet" (Pajnik, 2005:358) and its participatory democratic potential are critiqued by Pajnik for their lack of critical reflection upon the scope of citizenship shaped by a mediated society. A number of academic observers have argued the deployment of the edemocracy model in particular articulates a very thin understanding of political citizenship that is tied to voting and elections only (Coleman and Blumler, 2009). In addition, it is observed that this model of communication also fails to attract the attention of under-represented groups (Lindner and Riehm, 2010) thus replicating the issues of democratic deficit and inequalities of access that plagues real world political participation (Taylor, 2007). A much broader understanding of 'day-to-day' citizen political praxis is needed if Web 2.0 technology is to go beyond this "narrowing of citizenship to a voting practice” (Pajnik, 2005:356) by the 'usual suspects'.

Perhaps a more integral concern for its capacity to enable political dialogue is the commercialization of the net (or the dominant use of the web as a marketplace shaped by market laws rather than a place of democratic politics) which it is argued encourages consumer attitudes and a search for individualized solutions to problems rather than fostering association or collective political action (Bauman, 2005; Wellman et al. 2003). In this way you might say citizen consumer sovereignty is hard-wired into web-based technologies along with a utilitarian understanding of citizenship that 
champions (a negative) freedom of choice. Here Castells' (2011) 'network society' and Wellman et al. 's (2003) 'networked individualism' helps us understand that our shifting and multiple sets of online ties (of varying intensity) operate to extend citizen consumer realities, which in turn shape the potential for social media to re-politicise the public sphere. Pajnik in describing the exclusionary potential of this feature of the Internet describes a space of continuous self-expression where individuals construct and reconstruct their individuality in a way that risks marginalizing the "the emergence of a larger and more inclusive citizen public sphere" (ibid.p.355). Such attitudes encourage patterns of use typified by discussions between select groups of individuals (not an open inclusive public sphere) thus creating what Cass Sunstein (2001) characterized as "enclave deliberation” (p.75) and 'cyberbalkanisation' (Sunstein, 2007). In effect the inequalities of power and influence that exist in real world engagement are again transferred to the web (Hindman, 2009; Wilhelm, 2000). Yet Ellison and Harey (2012) would argue that this is not the ONLY potential outcome with evidence in their research of social media facilitating "interaction between local councils and citizens, this interaction taking the form of more or less extended 'conversations' hosted, but not dominated by local authorities" (p.13). We hope that in mapping the patterns of use and nature of discussions by citizens and local government via Web 2.0 platforms we will discover if these individualized and exclusionary trends continue to feature, or if the social media model is evolving to allow for further examples of more inclusive and open political dialogue.

The suggestion that Web 2.0 might remove the need for politics given that power (via freedom of information, knowledge, access) is (supposedly) universally available via these technologies (ref??) is heavily critiqued by parts of the academy (Isin and Wood, 1999; Pajnik, 2005). They argue this approach risks the extension of the post-political consensus generated by evacuating the public sphere of political debate and replacing it with a policy/political consensus around a neo-liberal economic agenda shaped by economic and political elites and consumer principles (Dahlgreen, 2000; Pajnik, 2005). Harvey's (1989) early observation of this urban politics trend of a "degraded local politics" (Evans et al. 2009:xx) at the hands of central state shaped procedural managerialism and consensus led governance is theorized as the 'post-political condition' (Swyngedouw, 2007). In this condition Swyngedouw $(2007,2008)$ and others have critiqued state-led consultation and public participation processes for their democratic deficit and lack of meaningful debate around political values an alternative to the hegemony of neo-liberal market-led economic growth (Baeten, 2009; Davidson, 2010, Deas, 2012). There is a risk that the use of social media by local councils compounds this condition through creating further state hosted (and so shaped) forums for discussions of low level issues (rather than deliberative political debate). Alternatively - as observed by Ellison and Hardey, (2012) - these extended conversations "hosted but not dominated by the local councils" (p.13) offer the beginnings of political conversations not "understood in strict deliberative terms" (p.15) but rather as "the space provided for reciprocity and the building of trust" (p.15). Critics have further 
argued that the faith in universal access fails to take account of (explicit and hidden) barriers to Internet accessibility owing to class divisions, geography, education, race, gender and age (Mossberger et al., 2003; Pajnik, 2005; Sunstein, 2007).

While there is a clear case that access by no means extends equally across the whole citizenry there is evidence of rapidly growing use with $80 \%$ of UK households having Internet access in 2012, (an increase of 23\% since 2006) (Foresight Future Identities, 2013). The same report goes on to illustrate evidence that since 2009 social media has become a majority activity in the UK with $60 \%$ of internet users (in 2011) also being members of a social media site (up from $47 \%$ in 2007) (ibid). This increase in use of social media extends beyond the obvious youth demographic with $18 \%$ of pensioners having their own account on a social network (ONS, 2011). Looking forward to the next decade Shewell (2013) describes the 'digital by default' connected 'Generation C' who will have grown up on digital technology and social media in a way that is likely to transform the way they connect with business, their communities and public services. Similarly, that hyper-connectivity was identified as one of the most significant factors by the Future Identities report as shaping citizen identity and practices in the next decade makes this current investigation all the more timely. The growth in access however, should by no means distract the debate from a significant percentage of people who for socio-cultural, physiological, material and physical reasons are digitally excluded (Mossberger et al., 2003; Sunstein, 2007) or to assume access logically will encourage rational and inclusive deliberation (Dean, 2003; Pappacharissi, 2002). Yet as the boundaries between online and offline identities are increasingly blurring and with social media simultaneously encouraging the growth of consumer cultures and/or "heightened awareness of political events elsewhere" (Foresight Future Identities, 2013:24) these technologies and cultures are evidently impacting the nature of political citizenship for a large element of society. While Ellison and Hardey (2012) acknowledge "this kind of participation is unlikely to resolve existing power inequalities" it is there assertion that "it does provide a way of giving local citizens increased political voice"(p.17). Loader and Mercea (2011) suggest a cautious approach is needed to the democratic renewal potential of social media while acknowledging "its disruptive value for challenging traditional interests and modes of communicative power" (p.757). The nature of this disruptive value and the impact this has on citizenship is central to moving this debate forward. To this end we argue the uncharted and under-researched local politics space and citizen political praxis that exists between the unrealized deliberative Habermasian ideal (Habermas, 1998), and the neo-liberal consensus of pre-determined post-political participation (Evans et al. 2009) is the theoretical and empirical focus of this paper and research project.

Like other arenas of this post-political critique - such as local community/state regeneration partnerships (Baeten, 2009; Raco, 2007; Swyngedouw, 2005, 2008) - local council use of Web 2.0 platforms can be presented as an additional technology of neo-liberal governance that enables the over-responsibilising of the 'active citizen' for social challenges in their communities beyond their 
control. This critical view extends to the expanding UK co-production and localist agendas and their associated state-determined understanding of political citizenship where the citizen-state relationship is characterized by greater citizen-choice, citizen-labour and citizen-responsibility (Davies and Pill, 2012; Deas, 2012; Newman and Clarke, 2009; Raco and Flint, 2012, Wallace, 2010). Evidently greater critical attention is needed to consider how (if at all) this prescribed view of political citizenship is manifest, recalibrated or erased by online political practices (social media norms). We must reflect on the control and ownership of content, and also on barriers to accessibility and influence for citizens on social media platforms. This focus has gained increased relevance since 2010 against a backdrop of unprecedented public sector cuts in the UK and the parallel Coalition government co-production agenda manifest in policy terms in the Localism Bill (DCLG, 2011) and Big Society (Lowndes and Pratchett, 2012; Taylor-Gooby and Stoker, 2011). Regardless of its questionable longevity or progressive social policy intentions Big Society continues to act as a catalyst for political debates in the UK around how we govern at a local scale, the balance of citizenstate relations in shaping or delivering public policy and what societal values we aspire to. It seems clear that Big Society (and the Localism infrastructure that makes up much of its substance) involves a re-imagining of the nature of citizenship as local councils are encouraged to secure greater local citizen participation in community governance (Straeheli, 2010:395). As a consequence careful attention must be paid to the nature, risks and progressive political potential of that shift in relations, not least of all how that plays out on social media. This English policy context of budget deficit reduction and increased devolution of central budgetary and planning powers to a local scale places a great deal of pressure on local councils to further engage citizens in local decision-making and even service delivery (Lowndes and Pratchett, 2012). In this context the Internet and Web 2.0 technologies have become an increasingly important tool to local government in the UK (Dutton, 2013; Shewell, 2011, 2013). This shift in the medium of engagement and the political praxis it encourages or marginalizes is central to this research.

For example, from a critical cultural perspective Pajnik (2005) highlights the exclusionary practices of ICT that have seen an often unchecked growth in racism and homophobia on the net, and social media in particular. While Richard Sennett also describes the Internet as facilitating a 'fetish of assertion' leaving little room for co-operation or expression of difference in dialogue. Instead, he describes the risk that some of the language and practices used in this virtual space often form "mental habits which discolour the blogosphere" (2012:26). He argues the complexities and nuances of face-to-face dialogue that allows for more than an information exchange between parties is often lost on the Internet, not least due to the absence of context to these exchanges (Sennett, 2012). Such conversational norms risk undermining the progressive political and social potential of Web 2.0 cultures and practices (and are apparent in the emerging research themes discussed below). Alternatively, social media may yet facilitate and act as a catalyst for new forms of social relations or 
bonds with political structures and social movements (Dutton, 2013; Loader and Mercea, 2013; Sennett, 2012) and it is both this potential and risk that underpins the purpose of this project.

\section{A critical reflection on citizenship and emerging political conversations}

By exploring in detail contemporary examples of local government use of social media to engage citizens the authors seek to understand further the critical space between the optimism of some libertarian commentators and the cautionary tales of the post-political counter-argument. Building on the sociological thesis proposed in Ellison and Hardey (2012) this paper outlines a framework - being explored through both the scoping and future project - of theoretical and practical possibilities and challenges for local level, small ' $p$ ' political conversations where citizens and local government engage in more informal dialogue about public services, processes of engagement and even modes of governance. Ellison and Hardey (2012) found through their desk-based survey of all 352 English councils that local authorities are largely "failing to engage with social media in any substantive manner" (p.1). From a local government communication practitioners perspective research into their use of social media also indicates the dominance of its continuing use as a broadcast one-way (Web 1.0) communication tool (Spurrell, 2012). While Shewell, (2011) and McCann (2012) note in the context of localist agendas there is a clear need for local councils to encourage their employees and councillors to become part of local conversations (either by initiating them or joining them) in order to show the council is a willing participant in open local dialogue.

Yet Ellison and Hardey do find pre-figurative examples of social media use in citizen engagement enabling what they describe as "this embryonic form of political communication" (p.1). They suggest a form of bottom-up less formally constituted open-ended political conversation between local government and citizens offers a new form of political praxis. A form of political citizenship that is perhaps better suited to the liquid modern environment/logic (Bauman, 2000) and that may complement rather than compete with or replace the less agile traditional institutions of representative democracy that are increasingly identified as the source of citizen political disenfranchisement (Castells, 2011). Ellison and Hardey (2012) argue that the Internet lacks the capacity for discipline and self-regulation that a large-scale deliberative democratic practice would demand, however, a more informal mode of participation is more realistic for such a fragmented and multifarious environment. Employing a more detailed case study analysis in revisiting these informal modes of participation (and associated political citizenship praxis) within the context of a rapidly maturing social media ecology is of pressing value given the pace of change in this field (Foresight Future Identities, 2013). As discussed above, the research has increasing policy purchase and relevance in the context of local government restructuring under new localist agendas that are requiring local councils in England to increase their scale of citizen engagement in local decision-making (Lowndes and Pratchett, 2012). In 
summary, given the context described above - of a broadly degraded local politics (Evans et al., 2009), rapid increase in use of social media in a liquid modern (Bauman, 2000) or networked society (Castells, 2011) and central state pressures to employ localist agendas - will these political conversations offer a response to familiar real world citizen engagement challenges and in so doing secure new practices of political citizenship that rearticulate citizen/state relations?

\section{"Developing Political Conversations? ... partnership and emerging themes}

"Developing Political Conversations? Exploring the citizen participation impact of the use of social media in local government" is a research bid that has been co-developed by a partnership of local council communications practitioners, third sector leaders and the authors. The objective of this project is to provide an in-depth case study to map and analyse the contemporary use of social media by three English local authorities (LA) in order to gain an understanding of their potential impact on the nature of citizen engagement, emerging forms of 'active' citizenship and shifting citizen-state relations in the context of the British governments' current localist agendas. The research bid has been co-produced by the partners in order to ask the following research questions:

RQ1: Which social media technologies are currently being used by each LA and how, if at all, are they being employed to enhance and/or change the nature of citizen participation?

RQ2: How and to what extent do social media platforms either complement or displace more traditional methods of citizen engagement (public meetings, consultation exercises, etc)?

RQ3: What impact (positive and negative) are social media technologies currently having upon 'stubborn' citizen engagement issues such as accessibility, depth of representation, tokenism, poor citizen feedback, consultation fatigue, democratic deficit and inequalities of power within stateshaped platforms (Gilchrist, 2006; Swyngedouw, 2007; Taylor, 2007)?

RQ4: What are the implications of these findings for the broader development of LA strategies for enhancing citizen engagement? How might the development of open 'political conversations' via social media within local political arenas contribute to more progressive (and nuanced) forms of localism?

If the bid is successful we intend to address these questions through an initial social media use mapping in each local council, followed by in-depth qualitative interviews with key local council members (e.g. democratic services, community development team, communications team, council 
members) and third sector stakeholders. The themes emerging from these initial stages will then be developed and tested in citizen focus groups and street surveys in each case study.

In building the research partnership and through initial scoping meetings with the partners it has already become evident there is a real appetite to understand the engagement potential of local council use of social media and the relations and cultural norms this disturbs or develops within local politics and citizen/state relations. What is also clear is that this is an embryonic form of local politics engagement in the UK where both citizens and local councils are tentatively feeling their way (at varying speeds and employing very different approaches). The progressive potential - in terms of political practices and cultures - of this means of engagement is present in the anticipatory and tentative steps taken by members of the research partnership in their day-to-day practice, but so too are the barriers, fears and exclusionary possibilities of Web 2.0 technologies in this local political context. Below we have outlined these emerging themes from the project scoping meetings with local council and third sector partners, and reflected on what these might mean for the broader research questions detailed above. We also consider how these compare to the results of recent large scale local government surveys on the use of social media for citizen engagement purposes in both England (Spurrell, 2012) and Australia (Purser, 2012).

In common with the Spurrell (2012) and Purser (2012) surveys our partners have all indicated they are using social media to engage citizens in a number of forms (predominantly via Twitter and Facebook) but are aware (in line with the Ellison and Hardey (2012) findings) that they are not fulfilling the potential of this medium of engagement. One partner acknowledged that as a sector local government is largely stuck in 'broadcast' mode and not fulfilling what he described as its 'transformative potential'. The motivation for being part of the research partnership for a number of the local council partners in particular is to understand how to overcome that stasis.

One concern raised in scoping meetings in this respect has been that a great deal of social media communication is still originating from the communications teams. Partners felt a barrier to a more progressive employment of social media can often be caused by a fear within the council over the control of social media communications and the 'message'. This is highlighted in the other surveys and wider commentary as being a direct barrier to accessing the full potential of open and transparent dialogue between local councils and citizens (Purser, 2012; Shewell, 2011; Spurrell, 2012; The Young Foundation, 2010). In the Spurrell (2012) survey $88 \%$ of council social media was handled solely by the communications team, while in the Australian example the figure was 66\% (Purser, 2012). This sensitivity to empowering all members of staff to be involved in these online conversations is naturally heightened as local and national elections approach in our case studies. That said in all three case studies both council officers and councillors currently use social media (and there is an appetite 


\section{DRAFT - PLEASE DO NOT CITE}

to spread the extent of this use), however, there is an anxiety over when that goes 'wrong' with examples of councillors making inappropriate comments and the damage limitation this required.

Regardless of the benefits of trying to extend the ownership of social media communication to all council staff and political members the resources are often not available (in an austerity context) for this to be a communications team only role anyway, and the concern over how to fund this growing (but increasingly important) aspect of their remit was a concern for some partners just as it was in the Purser (2012) survey. Social media as a medium generates an expectation of rapid if not real time response that in itself creates resourcing issues. That said the potential for increased efficiency and effectiveness of the reach of social media communications (The Young Foundation, 2010) was acknowledged by partners as a balancing consideration to this practical resource issue. Further, regardless of cost barriers there are plans in place in all three case studies to increase the types of areas of use of social media. This extends to the political process itself with one council introducing web-streaming of council meetings and a Twitter wall at the meeting to extend the dialogue via questions from Twitter users. It was evident throughout the initial scoping that social media will play a role in future efforts to address citizen disengagement and disenfranchisement from the local political process. For example, partners discussed using social media in trying to engage citizens where rural isolation or being time poor would ordinarily make that engagement difficult. This approach was also evident in using social media to engage a younger demographic with the help of the youth councils.

The challenge of measuring who is engaging with the local council through their social media was repeatedly raised by partners as an issue for trying to understand if and how this platform could be used as hoped to engage hard-to-reach communities. Similarly, the Purser (2012) Australian survey showed $25 \%$ of councils "believed that social media would specifically assist them to engage with hard to reach segments of the community including youth, those with disabilities, seniors and time poor families" (p.8). All of our partners are looking to gain insight into which citizens within their incredibly diverse demographic is using this form of engagement and why, and perhaps more importantly who is not and why. They want to know what socio-cultural, economic, psychological, geography, skills based and other barriers there are to this form of engagement with some articulating concerns over the likelihood of traditional barriers to engagement being simply transferred to on-line debate. While all three case studies can see an increase in the scale of their social media following the concern is that at this stage that following is the usual vocal white middle class demographic that have transferred their political energies to social media platforms. This evidently needs further critical attention and both the local councils and third sector partners want to work to explore how social media is eroding or embedding pre-existing barriers to engagement. In doing so we hope to identify practices that might enable councils and citizens to fulfil the more progressive and transformative potential of Web 2.0 technologies (and cultural norms) in local politics (Ellison and Hardey, 2012). 
In terms of extending who is using social media beyond the communications team one of the case studies had recently started introduced social media training workshops for councillors. In the Australian example only 9\% of councils provided this for their elected representatives (Purser, 2012). Further, two of the case studies noted that as a younger generation of councillors came forward, the council's existing fears over the potential damage to the council reputation, or even how to use social media was slowly diminishing. Indeed they indicated an emerging expectation of social media being part of future local politics, suggesting further evidence of the 'digital by default' Generation C (Future Identities Report, 2013; Shewell, 2013) impacting the nature of local government/citizen dialogue. However, this shift is clearly by no means a painless or even process with examples described of the two different political cultures experiencing early clashes. Council and third sector partners described resistance from some older council members and a tension building as a new set of political norms emerge with the increased transparency, pace, and accessibility (for some) of social media communications disturbing the more bureaucratic and slower moving governance norms of traditional local politics.

Partners described how the discomfort for some local council members with Web 2.0 cultural norms became explicit in examples where the political conversation was not initiated or hosted by the local council (e.g. through neighbourhood websites). The fear for some third sector partners is that local government use of social media will simply reproduce the practices of poor citizen engagement that has plagued local government in the UK for some time (Evans and Jones, 2008). The political/cultural clash has also emerged where some councils/councillors have received aggressive and personal attacks on Twitter or Facebook as the traditional rules of courtesy and diplomacy that shape (some) off-line political debate appear often absent in the informal conversations of social media (as also observed in the work of Pajnik, 2005 and Sennett, 2012). Learning how to handle this in an open and positive way going forward is clearly a challenge for this form of political conversation. Yet all partners had examples of where that challenge had been handled well, or where the use of social media by the council to communicate with citizens had a very 'humanising' effect where more formal modes of engagement had often historically alienated citizens. This was an observation echoed in the Purser (2012) survey and also in UK case studies described by BDO Local Government (2012).

Interestingly all three case studies from a council and third sector perspective observed that practical emergency communications via social media between the local council and citizens (for example during localised floods and snow blocked roads) was acting as a catalyst to further engagement at a more political and strategic level. This echoed the findings in the Australian survey showing communications during the floods and cyclone in Queensland in 2011 had proved a positive introduction to this form of engagement (Purser, 2012). This element of engagement around the delivery of services is an experience the third sector partners in particular are building upon in all 
areas of service delivery and needs based consultation. One third sector partner explained that they are increasingly finding that normal partnership modes of citizen engagement that come together based around place are very quickly becoming moribund as citizen volunteers want more fixed time /fixed topic projects rather than extended engagement. In this respect it was felt that the Internet (and social media in particular) will offer the potential for that rapid mode of engagement. Third sector partners expressed concerns over the time premium for 'active citizens' who are already demonstrating consultation fatigue. Consultation fatigue is an issue brought into sharp focus by the necessity of citizen engagement for the success of Big Society and broader Coalition government localist agendas (Lowndes and Pratchett, 2012). In this respect partners were hopeful social media based public engagement in local government decision-making would have the potential to ease some of this pressure with its more informal tone, temporal and place-based flexibility, cost-savings, ease of access to information and rapid response potential. Of course this form of engagement and the liquid modern logic of social media encourages the mixing of citizen consumer and political citizenship praxis in the style of 'new public management' that Sunstein, (2007) and others warn against. Yet Ellison and Hardey (2012) suggest we "accept this de facto elision" (ibid:17) and further accept this is a way of creating a space for "citizens to engage if they choose to do so, hear others' views, and receive responses directly from elected members" (ibid:17) in a prompt and timely fashion. In this way social media practice and norms may remedy some of the issues with off-line engagement that leaves citizens feeling their view has no impact upon local decision-making.

The initial evidence from scoping conversations has highlighted examples of risks of social media use for local councils in terms of democratic deficit, conflict over the control of the message communicated, challenges for universal access, citizen consultation fatigue, practical delivery challenges for fielding social media engagement and political cultural clashes. Yet it has also indicated that a very different local political engagement culture is developing with as yet underrealised and under-researched possibilities. In exploring this mode of engagement further we will be asking if the citizen norms this facilitates encourages alternative practices of (political) citizenship. This line of enquiry introduces broader research questions concerning the possibility of a shift in local government from broadcast communications and a post-political condition of governance to a public sphere of open (and non-consensual) political conversations. Finally, but importantly will this approach rebalance the geometries of power between citizens and the local state and so doing begin to address the malaise of disengagement and disenfranchisement with the processes and agents of local politics.

\section{References}




\section{DRAFT - PLEASE DO NOT CITE}

Anduiza, E., Cantijoch, M. and Gallego, A. (2009) 'Political participation and the internet" a field essay', Information, Communication and Society, vol 12, no 6, pp. 860-78.

Baeten, G. (2009) Regenerating the South Bank: reworking community and the emergence of postpolitical regeneration. In: Imrie, R., Lees, L., and Raco, M., (eds). Regenerating London: Governance, sustainability, and community in a global city. Oxon: Routledge, 237-253

Bauman, Z. (2000) Liquid Modernity, Polity Press, Cambridge.

Bauman, Z. (2005) Liquid Life, Polity Press, Cambridge.

BDO LLP (2012) From housing and litter to Facebook and Twitter, BDO LLP, London

Castells, M. (2011) Communication Power, Oxford University Press, Oxford.

Coleman, D. and Blumler, J. (2009) The Internet and Democratic Citizenship: Theory, Practice and Policy, Cambridge University Press, Cambridge.

Dahlberg, L. (2001) 'The internet and democratic discourse: exploring the prospects of online deliberative forums extending the public sphere', Information, Communication and Society, 4 (1), 615-33.

Davidson, M. (2010) Social sustainability and the city. Geography Compass, 4 (7), 872-880

Davies, J. S. and Pill, M. (2012) Empowerment or abandonment? Prospects for neighbourhood revitalisation under the big society. Public Money and Management, 32, (3), 193-200

Deas, I. (2012) Towards post-political consensus in urban policy? Localism and the emerging agenda for regeneration under the Cameron government. Planning Practice and Research, DOI:10.1080,02697459.2012.699228, pp.1-18

Dean, J. (2003) 'Why the net is not a public sphere', Constellations, 10 (1), 95-112.

Department for Communities and Local Government (2011) The Localism Bill, available at http://www.communities.gov.uk/localgovernment/decentralisation/localismbill/ (March 16 2012).

Dutton, W.H. (ed.) (2013) The Oxford Handbook of Internet Studies. Oxford: Oxford University Press

Dutton, W. H. and Blank, G. (2011) Next generation users: The internet in Britain, Oxford Internet Survey 2011 Report, Oxford Internet Institute, Oxford. 


\section{DRAFT - PLEASE DO NOT CITE}

Ellison, N. and Hardey, M. (2012) Developing Political conversations? Information, Communication and Society, DOI:10.1080/1369118X.2012.740495, pp.1-20

Evans, J., and Jones, P. (2008) Rethinking sustainable urban regeneration: ambiguity, creativity, and the shared territory. Environment and Planning, 40, 1416-1434

Evans, J., Jones, P., and Krueger, R. (2009) Organic regeneration and sustainability or can the credit crunch save our cities? Local Environment, 14, (7), 683-698

Featherstone, D., Ince, A., MacKinnon, D., Strauss, K., and Cumbers, A. (2012) Progressive localism and the construction of political alternatives. Transactions of the Institute of British Geographers, 37, $177-182$

Foresight Future Identities (2013) Final Project Report. The Government Office for Science, London.

Gilchrist, A. (2006) Partnership and participation: power in process. Public Policy and Administration, $21,70-85$

Habermas, J. (1998), The structural transformation of the public sphere, Polity Press, Cambridge.

Hindman, M. (2009) The myth of digital democracy. Princeton University Press, Princeton.

Lindner, R. and Riehm, U. (2010) 'Broadening participation through e-petitions? Results from an empirical study on petitions to the German parliament', unpublished paper, Fraunhofer Institute for Systems and Innovation Research, Karlsruhe, Germany.

Lowndes, V. and Pratchett, L. (2012) Local governance under the Coalition Government: austerity, localism and the "Big Society", Local Government Studies, 38 (1), 21-40.

Loader, B. D. and Mercea, D. (2011) Introduction networking democracy? Social media innovations and participatory politics, Information, Communication and Society, 14 (6), 757-769.

McCann, K. (2012) Should communications teams relax control of social media? The Guardian, Tuesday $7^{\text {th }}$ February, 2012. Available online at: http://www.guardian.co.uk/local-governmentnetwork/poll/2012/feb/07/poll-relinquish-control-over-social-media [Accessed on 16.4.2013].

Miller, L. (2009) 'e-Petitions at Westminster: the way forward for democracy?' Parliamentary Affairs, $62,(1), 162-177$

Mossberger, K., Tolbert, C. and Stansbury, M. (2003) Virtual inequality: beyond the digital divide. Georgetown University Press, Washington DC. 


\section{DRAFT - PLEASE DO NOT CITE}

Newman, J. and Clarke, J. (2009) Publics, Politics and Power: Remaking the Public in Public Services. Sage, London.

Norris, P. (1999) Who surfs? New technology, old voters and virtual democracy, in E.C. Kamark and J.S. Nye (eds) Democracy.com? - Governance in a network world. Hollis, New Haven.

O’Reilly, T. (2010) ‘Government as a Platform', in D. Lathrop and L. Ruma (Eds.), Open

Government: Collaboration, Transparency and Participation in Practice, O'Reilly Media, Sebastopol.

Office for National Statistics (2011) Internet Access - Households and Individuals,

2011. Released: 31 August 2011

Pajnik, M. (2005) Citizenship and mediated society. Citizenship Studies, 9 (4), 349-367

Pappacharissi, Z. (2002) 'The virtual sphere: the internet as a public sphere', New Media and Society, $4(1), 9-27$.

Purser, K. (2012) Using Social Media in Local Government: 2011 Survey Report, Australian Centre of Excellence for Local Government, University of Technology, Sydney.

Raco, M. (2005) Sustainable development: rolled out Neoliberalism and sustainable communities. Antipode, 37, 324-347

Raco. M. and Flint, J. (2012) Characterising the 'new' politics of sustainability: from managing growth to coping with crisis. in: Flint, J. and Raco, M. (eds.) Sustaining Success: The New Politics of Sustainable Urban Planning, Policy Press: Bristol, 3-28

Rheingold, H. (2000). The Virtual Community: Home-steading on the Electronic Frontier, MIT Press, Cambridge, MA.

Shewell, J. (2011) 'Social media in the public sector', Whitepaper 14, Public Relations Whitepaper Series, DWPub, Daryl Willcox Publishing, Brighton.

Shewell, J. (2013) Stepping up to the challenge of digital, Brand Republic, January 2013, Haymarket Business Media, London.

Spurrell, D. (2012) An opportunity or a threat? How local government uses social media today. The Guardian, Tuesday $7^{\text {th }}$ February, 2012. Available online at: http://www.guardian.co.uk/localgovernment-network/2012/feb/07/local-government-social-media-today [Accessed on 22.1.2013]

Sennett, R. (2012) Together. The rituals, pleasures and politics of cooperation. Penguin Books Ltd, London 


\section{DRAFT - PLEASE DO NOT CITE}

Staeheli, L.A. (2011) Political geography: Where's citizenship?. Progress in Human Geography. 35, $393-400$

Sunstein, C. (2001) Republic.com, Princeton University Press, Princeton.

Sunstein, C. (2007) Republic.com 2.0, Princeton University Press, Princeton.

Swyngedouw, E. (2005) Governance innovation and the citizen: The Janus face of governance beyond the state. Urban Studies, 42, (11), 1991-2006

Swyngedouw, E. (2007) Impossible 'sustainability’ and the postpolitical condition. In: Krueger, R., and Gibbs, D. (eds). The Sustainable development paradox: Urban Political Economy in the United States and Europe. Guildford Press: New York, 13-40

Swyngedouw, E. (2008) Where is the political? University of Manchester Working Paper, Available from: http://www.socialsciences.manchester.

ac.uk/disciplines/politics/research/hmrg/activities/documents/Swyngedouw.pdf [Accessed: 28 August, 2010]

Tapscott, D. (2009) Grown up Digital, McGraw Hill

Taylor, M. (2007) Community Participation in the real world: Opportunities and pitfalls in new governance spaces. Urban Studies, 44, (2), 297-317

Taylor-Gooby, P. and Stoker, G. (2011) The Coalition programme: A new vision for Britain or politics as usual? The Political Quarterly, 82 (1), 4015

The Young Foundation (2010) Listen, Participate, Transform. A social media framework for local government. A Local 2.0 think-piece. The Young Foundation, June 2010.

Wallace, A. (2010) New Neighbourhoods, New Citizens? Challenging Community as a Framework for Social and Moral Regeneration under New labour in the UK. International Journal of Urban and Regional Research no. doi: 10.1111/j.1468-2427.2009.00918.x, 1-15

Wellman, B., Quan-Haase, A., Boase, J., Chen, W., Hampton, K., Diaz, I. and Miyata, K. (2003) 'The social affordances of the internet for networked individualism', Journal of Computer-Mediated Communication, 8 (3), 0-0.

Wilhelm, A. (2000), Democracy in the Digital Age: Challenges to Political Life in Cyberspace, Routledge, London. 


\section{DRAFT - PLEASE DO NOT CITE}

Zavestoski, S., Shulman, S. and Schlosberg,D. (2006) 'Democracy and the environment on the internet: electronic citizen participation in regulatory rulemaking', Science, Technology and Human Values, 31 (4), 383-408. 